\title{
Evidence that Xylella fastidiosa Can Cause Leaf Scorch Disease of Pecan
}

\author{
R. S. Sanderlin and K. I. Heyderich-Alger, Louisiana State University Agricultural Center, Pecan Research- \\ Extension Station, P. O. Box 5519, Shreveport 71135
}

\begin{abstract}
Sanderlin, R. S., and Heyderich-Alger, K. I. 2000. Evidence that Xylella fastidiosa can cause leaf scorch disease of pecan. Plant Dis. 84:1282-1286.

The disease known as pecan fungal leaf scorch has been reported to be either caused by or associated with several fungi since it was first recognized in 1972. Data are presented that indicate the disease is initiated by the fastidious xylem-limited bacterium Xylella fastidiosa. X. fastidiosa was found consistently associated with fungal leaf scorch disease of pecan (Carya illinoinensis) in commercial orchards in Louisiana. It was generally not detected in symptomless trees. The disease was reproduced by inoculation of greenhouse seedlings and grafted trees with cultures of the bacterium obtained from leaves with fungal leaf scorch. The bacterium was reisolated from symptomatic tissue of inoculated pecan seedlings, but not from symptomless plants inoculated with water to complete Koch's postulates. It is proposed that the name of the disease be changed to pecan bacterial leaf scorch because fungi do not appear to be necessary for symptom development.
\end{abstract}

Additional keywords: xylem-limited bacteria

Several different forms of leaf scorch maladies have been reported on pecan (Carya illinoinensis) and attributed to various causes, such as nutritional imbalances and environmental extremes $(1,6,36)$. In 1972, four genera of fungi (Pestalotia, Epicoccum, Curvularia, and Fusarium) were reported to have a significant correlation with a particular type of leaf scorch (20). Symptoms of this scorch were described as necrotic areas that first appeared on the tips or margins of leaflets and progressed toward the midrib. The advancing necrosis was often defined by a black margin, and affected leaflets abscised $(21,37)$. The scorch began in August and became more severe over time $(21,37)$. Data were reported that indicated effective control of the leaf scorch problem by several fungicides $(21,37)$. Because of the association of several fungi with leaf scorch and efficacy of fungicides against symptom development, it was assumed that the leaf scorch described by Littrell and Worley was caused by fungi $(21,22,37)$. The name fungal leaf scorch (FLS) was first applied to the particular symptomatology in 1974 (18) and has been the accepted common name (7).

In 1994, a Phomopsis sp. was reported to cause symptoms of FLS (30). When cv. Curtis seedlings were inoculated with a

Corresponding author: R. S. Sanderlin

E-mail: rsanderlin@agctr.1su.edu

Accepted for publication 28 August 2000.

Publication no. D-2000-1005-01R

(C) 2000 The American Phytopathological Society spore suspension of the Phomopsis sp. isolated from leaves with the disease, symptoms similar to FLS began to develop within 24 h (30).

Symptoms occurred only on the portion of the leaflets where inoculum was applied, and a Phomopsis sp. was recovered from the inoculated leaves (30). In 1995, another fungus, Glomerella cingulata, was reported to cause FLS. Cv. Schley trees inoculated with a spore suspension of $G$. cingulata obtained from pecan shuck tissue developed symptoms similar to FLS over a 60day period (16). A Glomerella sp. was isolated from $84 \%$ of the leaves with symptoms, and no FLS developed on the check trees (16). In 1998, an association of the fastidious xylem-limited bacterium Xylella fastidiosa with leaflets exhibiting symptoms of FLS was reported (31).

This article presents data to support the hypothesis that $X$. fastidiosa is able to cause the leaf scorch disease of pecan without the involvement of fungi. X. fastidiosa appears to be the primary pathogen; therefore, a new common name is proposed for this disease: pecan bacterial leaf scorch.

\section{MATERIALS AND METHODS}

Association of $X$. fastidiosa with leaf scorch. Initial tests at the Louisiana State University Agricultural Center Pecan Research-Extension Station had shown $X$. fastidiosa to be in rachis tissue from leaves with FLS and usually not in nonsymptomatic tissue (31); therefore, a survey of pecan orchards in Louisiana was undertaken to determine if this association was consistent. Only one cultivar, Cape Fear, was included in this survey because Cape
Fear is very susceptible to the malady known as FLS (23) and produces distinct symptoms that reduce the confusion that can occur from other causes of leaf scorch, such as nutritional imbalances (19).

Ten leaves with symptoms were collected from each of 10 Cape Fear trees in commercial orchards. Ten leaves without symptoms also were collected from each of 5 or 10 trees that either had no scorch symptoms or had a low level of disease severity. If Cape Fear trees without symptoms could be found at a location, they were sampled in addition to another cultivar with no or low levels of scorch. In some orchards, Cape Fear trees without symptoms could not be located and another cultivar was used for assay of symptomless tissue.

Leaf samples were placed into plastic bags and stored on ice for transport to the laboratory. The samples were stored overnight at 2 to $4^{\circ} \mathrm{C}$ and assayed the next day. Rachis tissue was assayed for the presence of $X$. fastidiosa with a commercial enzyme-linked immunosorbent assay (ELISA) kit (Agdia, Elkhart, IN). A section about $4 \mathrm{~cm}$ long was cut from each of the 10 rachises in a leaf sample. The rachis sections were ground with a mortar and pestle in 4 to $5 \mathrm{ml}$ of Agdia extraction buffer. Extracted samples were kept refrigerated until all samples had been prepared for the assay. The assays followed the standard protocol for the ELISA kit.

Isolation and culture of $X$. fastidiosa. $X$. fastidiosa was cultured from leaf scorch-diseased tissue by the following procedure. Rachises from Cape Fear leaves with scorch were rinsed under a stream of running water, dried with paper towel, then cut into lengths of 2.5 to $5 \mathrm{~cm}$. Sterile needle-nosed pliers were used to squeeze a drop of sap to the surface of a cut end of a rachis section. The drop was removed with a sterile $25-\mu \mathrm{l}$ capillary tube and deposited onto the surface of periwinkle wilt agar (PWA; 4,32). PWA dishes inoculated with sap drops were incubated at 26 to $29^{\circ} \mathrm{C}$ in darkness and examined periodically for typical colonies of $X$. fastidiosa for about 6 weeks (28). Bacterial colonies that were suspected to be $X$. fastidiosa were transferred to fresh PWA and identified by ELISA with the commercial test kit.

Plant sources. Seedlings for inoculation were grown from Cape Fear seed collected from trees at the Pecan Research-Extension Station. Seed was planted into 25-by-25$\mathrm{cm}$ plastic pots in February and May 1998. Trees with Cape Fear scions were pur- 
chased as bare-root trees from a commercial nursery in December 1998. These were transplanted into 51-by-25-cm plastic pots. The grafted trees were about 1 year old at the time of purchase and 1.2 to $2 \mathrm{~m}$ in height. The seedlings were always kept in a greenhouse and the grafted trees were maintained outside until used for inoculation.

Inoculation. Bacterial isolates to be inoculated into plants were grown on PWA at 26 to $29^{\circ} \mathrm{C}$ in darkness for 15 to 23 days. Inoculum was prepared by scraping colonies from the agar surface and suspending in sterile distilled water. ELISA was used to confirm the identity of the cultures as $X$. fastidiosa. Inoculum suspensions were made from five isolates that had been obtained from Cape Fear trees with leaf scorch. Four of the isolates were cultured from trees at the Pecan Research-Extension Station and one isolate was obtained from a commercial orchard in Natchitoches Parish, Louisiana. Each plant was inoculated with one isolate. $\mathrm{A}_{600 \mathrm{~nm}}$ of the inoculum suspensions ranged from 0.2 to 0.57 .

All plants used for inoculation tested negatively for $X$. fastidiosa by ELISA within 2 days prior to being inoculated. There were no visible symptoms of scorch on any of these plants before inoculation. The needle puncture procedure was used to apply the inoculum (13). A 10- $\mu$ l drop of inoculum was placed on the plant stem and a dissecting needle pushed through the drop into the stem. Generally, the drop was absorbed into the puncture while the needle was still in the stem or within a few seconds after the needle was withdrawn. Ten $10-\mu l$ drops were applied to each plant. The Cape Fear trees were inoculated by the same procedure using a tapered awl to puncture the trunk because of the greater thickness and density of the wood. On the seedlings, punctures were made from 5 to $30 \mathrm{~cm}$ above the soil line. Punctures on the grafted trees were made from above the soil line to near the tip of the trunk. Following inoculation, all plants were maintained in a greenhouse. The greenhouse temperature over the course of the observation period was 13 to $41^{\circ} \mathrm{C}$. Control plants were inoculated with distilled water by the same procedure.

One inoculation test was started on 29 September with two isolates. A second test began on 7 October with two isolates, and the third test with one isolate started 4 November. The first two tests used the isolates from the Pecan Research-Extension Station, and the third test used the isolate from Natchitoches Parish. All isolates had been obtained in August and maintained on PWA through biweekly transfer.

Inoculated plants were monitored for development of leaf scorch symptoms. When symptoms became apparent, ELISA tests were used to verify the presence of $X$. fastidiosa. Attempts were made to culture the bacterium from leaves that tested positive and from symptomless leaves of water-inoculated plants using the previously described technique. ELISA was used to verify cultures as $X$. fastidiosa.

Isolation of fungi. Fungi were cultured from plants used in the inoculation tests. Sections (about $5 \mathrm{~mm}^{2}$ ) of leaf tissue were cut from the area of the interface of necrotic and green tissue of plants that develmoved from senescent leaf tissue of the water-inoculated plants. Leaf tissue sections were surfaced cleaned in either $0.5 \%$ sodium hypochlorite or $70 \%$ ethanol for 1 min, then rinsed in sterile distilled water and plated onto potato dextrose agar (PDA). Fungi that grew from the leaf sections were transferred to fresh PDA and identified by microscopic examination of spores.

\section{RESULTS}

Association of $X$. fastidiosa with leaf scorch. During the orchard survey, X. fastidiosa was consistently detected in Cape Fear with leaf scorch symptoms using ELISA. Disease symptoms were first observed in June and increased in incidence and severity throughout the summer. $\mathrm{Ne}$ crosis began at the tip or margin of leaflets and progressed toward the midrib. The necrotic tissue usually had a light brown or tan coloration. Necrosis often began on the older leaflets at the base of a rachis and progressed to the younger pairs of leaflets. Defoliation tended to follow the same pattern. It was common to observe compound leaves with leaflets remaining at the tip of an otherwise defoliated rachis. With time, a terminal may have only bare rachises attached or exhibit complete leaf loss. Many of the affected leaflets had a band of dark brown or reddish-purple tissue at the interface of the necrotic and green tissue. The pattern of disease development within orchards was variable. In some orchards, all trees of Cape Fear that were observed had symptoms of leaf scorch. In other orchards, only a few trees exhibited symptoms without any obvious pattern of disease distribution. On some affected trees, almost every limb had leaves with scorch; oped scorch. Similar sections were re-

in other trees, symptoms were confined to one or a few limbs.

Cape Fear trees with leaf scorch from seven orchards were assayed by ELISA. The bacterium was detected in 64 of 70 $(91 \%)$ of these trees (Table 1). The six trees from this group that assayed negatively were from one location where scorch symptoms were just beginning to develop and severity was mild. It was not possible to find Cape Fear trees without scorch symptoms in five of the seven orchards. One of the two orchards with symptomless Cape Fear was the orchard with early, mild symptoms. The five Cape Fear trees with no symptoms that were assayed from this orchard were negative for the bacterium. In the other orchard that had some symptomless Cape Fear trees, all 10 trees tested were negative. In one of the orchards in Rapides Parish, no cultivar was identified as being disease free. Five trees of 'Cheyenne' were assayed that had scorch symptoms limited to distinct limbs. Leaves were taken from terminals without symptoms; however, four of these five trees assayed positive for $X$. fastidiosa. At a location in Ouachita Parish, two of five symptomless trees of 'Moreland' also assayed positive for the bacterium. Overall, 6 of 45 (13\%) symptomless foliage samples from seven orchards that included six cultivars (Cheyenne, Caddo, Candy, Moreland, Melrose, and Stuart) were positive for the bacterium (Table 1).

Culture of $X$. fastidiosa from scorched diseased tissue. During August 1999, X. fastidiosa was cultured from 16 samples of diseased leaves of Cape Fear. Colonies of the bacterium were visually identified by typical growth on PWA. Small (0.1 to 1.0 $\mathrm{mm}$ ), white, dome-shaped colonies of bacteria were visible in 2 to 3 weeks after rachis sap was placed on the medium. All colonies were subcultured and verified as $X$. fastidiosa by ELISA. The bacterium was cultured regularly from scorch-diseased rachises, but not all culture attempts were successful. Attempts to culture the bacterium from symptomless Cape Fear tissue were negative.

Inoculation of pecan with $X$. fastidiosa and development of leaf scorch symptoms. In a series of three inoculation tests,

Table 1. Association of Xylella fastidiosa with pecan leaf scorch disease ${ }^{\text {a }}$

\begin{tabular}{lcccc}
\hline & \multicolumn{2}{c}{ Cv. Cape Fear } & & \\
\cline { 2 - 3 } Location & With scorch & Without scorch $^{\mathbf{b}}$ & Other cultivars & Without scorch \\
\hline Rapides & $10 / 10$ & $\ldots$ & Cheyenne & $4 / 5$ \\
Rapides & $10 / 10$ & $\ldots$ & Caddo & $0 / 5$ \\
Ouachita & $10 / 10$ & $\ldots$ & Moreland & $2 / 5$ \\
Ouachita & $10 / 10$ & $\ldots$ & Candy & $0 / 5$ \\
Natchitoches & $10 / 10$ & $0 / 10$ & Stuart & $0 / 5$ \\
Natchitoches & $4 / 10$ & $0 / 5$ & Candy & $0 / 10$ \\
Grant & $10 / 10$ & $\ldots$ & Melrose & $0 / 10$ \\
\hline
\end{tabular}

a Determined by enzyme-linked immunosorbent assay with commercial kit (Agdia, Elkhart, IN).

b Numerator is the number of trees that were positive for X. fastidiosa, and denominator is the number of trees assayed.

${ }^{c}$ Louisiana parish where commercial production orchard was located. 
32 seedlings of Cape Fear and 11 trees in pots grafted to Cape Fear were inoculated with $X$. fastidiosa. Symptoms of leaf scorch disease were first observed in early January on some of the plants inoculated in each of the three tests and were typical of symptoms observed in orchards (Fig. 1). Observations recorded through the middle of January indicated a total of 15 seedlings and five grafted trees with symptoms of leaf scorch (Table 2). Most of the affected leaflets had the dark band of tissue sepa- rating the green from the necrotic tissue. Of the 15 seedlings, 13 assayed positive for $X$. fastidiosa by ELISA. Two of the five grafted trees inoculated with the bacterium that developed symptoms were positive in ELISA. None of the 13 seedlings inoculated with water developed any symptoms of leaf scorch. One of the eight grafted trees that had been inoculated with water did develop scorch symptoms, but was negative in the ELISA test. These trees had been grown outside in a nursery

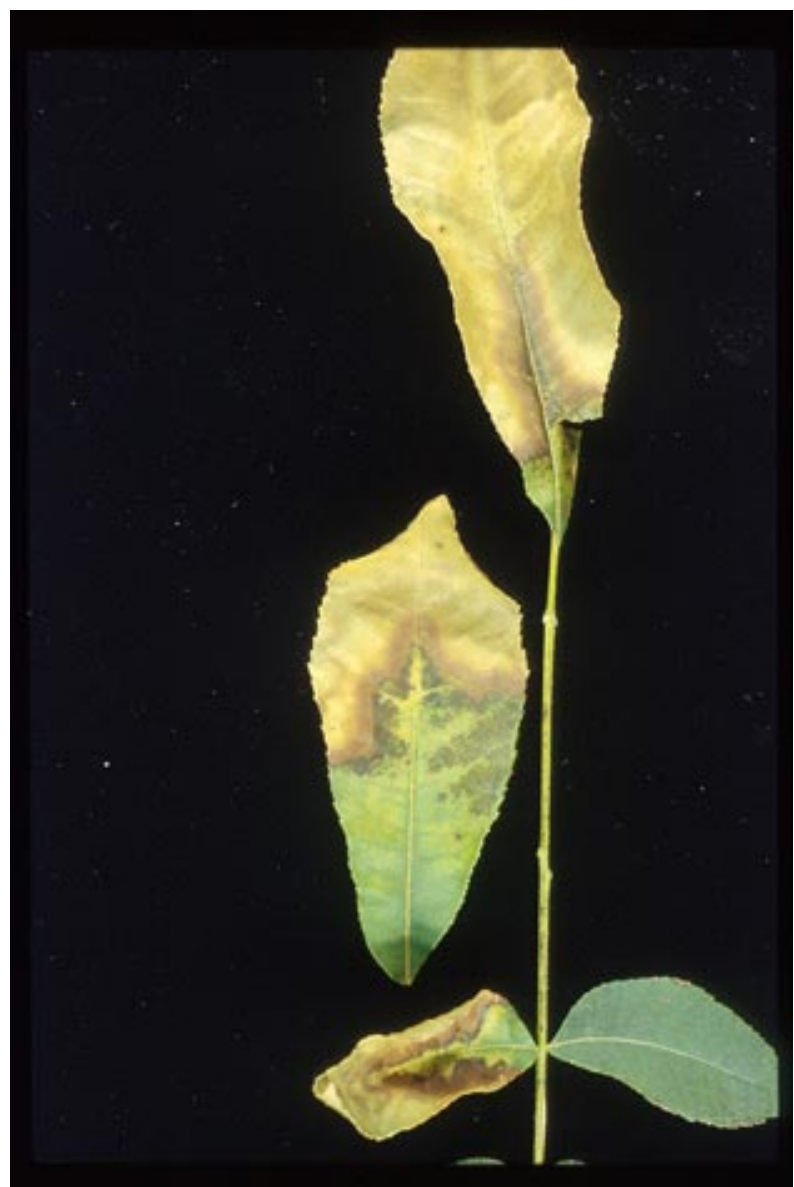

Fig. 1. Pecan bacterial leaf scorch on foliage of Carya illinoinensis 'Cape Fear' seedling inoculated with Xylella fastidiosa.

Table 2. Development of leaf scorch in pecan seedlings and grafted trees of pecan cv. Cape Fear inoculated with Xylella fastidiosa and reisolation of the bacterium

\begin{tabular}{|c|c|c|c|c|}
\hline \multirow[b]{2}{*}{ Isolate $^{b}$} & \multicolumn{2}{|c|}{ Development of disease $^{\mathrm{a}}$} & \multicolumn{2}{|c|}{ Reisolation from symptomatic tissue } \\
\hline & Seedlings & Grafted & Seedlings & Grafted $^{\mathrm{c}}$ \\
\hline 2 & $0 / 6$ & $1 / 1$ & $\ldots$ & $0 / 1$ \\
\hline 5 & $5 / 5$ & $1 / 2^{\mathrm{d}}$ & $4 / 5$ & $\ldots$ \\
\hline 10 & $4 / 5$ & $2 / 2^{\mathrm{d}}$ & $0 / 1$ & $0 / 2$ \\
\hline 11 & $2 / 6$ & $1 / 1$ & $1 / 1$ & $0 / 1$ \\
\hline 14 & $4 / 10$ & $0 / 5$ & $2 / 3$ & $\ldots$ \\
\hline
\end{tabular}

${ }^{a}$ Isolates of $X$. fastidiosa were obtained from 'Cape Fear' leaf tissue with scorch symptoms and cultured on periwinkle wilt agar. Isolates 2 and 11 were used in the test started 29 September, isolates 5 and 10 were used in the test started 7 October, and isolate 14 was used on 4 November.

${ }^{b}$ Numerator is the number of plants that developed visible symptoms of leaf scorch and gave a positive enzyme-linked immunosorbent assay (ELISA) reaction for $X$. fastidiosa, and the denominator is the number of plants inoculated with the respective isolate.

${ }^{\mathrm{c}}$ Numerator is the number of inoculated plants from which the bacterium was cultured, and the denominator is the number of plants with which attempts to culture were made.

${ }^{\mathrm{d}}$ Recorded with visible scorch symptoms, but negative for X. fastidiosa in ELISA.

prior to their inoculation, and natural infection may have occurred even though they assayed negative for the bacterium prior to inoculation. The bacterium was cultured from 7 of 10 symptomatic seedlings with which reisolation attempts were made. It was not recovered from grafted trees with symptoms.

Fungi and leaf scorch. Previous reports indicated that different fungi could either cause leaf scorch or were associated with it; therefore, attempts were made to culture fungi from the tissue exhibiting leaf scorch on inoculated plants. Genera of fungi that were recovered from inoculated plants that developed leaf scorch symptoms included Alternaria, Epicoccum, Fusarium, Phoma, and Cladosporium. Three of these also were cultured from senescent leaf tissue of the symptomless water-inoculated plants. Epicoccum and Phoma spp. were not recovered from the water-inoculated plants, but were found in one sample each of the tissue with leaf scorch.

\section{DISCUSSION}

The consistent association of X. fastidiosa with leaf scorch in orchards, the ability of the bacterium to cause the disease in inoculated seedlings and grafted trees, and the recovery of $X$. fastidiosa from the diseased tissue fulfills Koch's postulates and indicates that the bacterium is the primary cause of the malady known as FLS.

The two fungi most recently reported to cause leaf scorch, a Phomopsis sp. (30) and Glomerella cingulata (16), were not recovered from the greenhouse-grown plants inoculated with $X$. fastidiosa that developed the disease. Five genera of fungi were recovered from the leaf scorch tissue following inoculation. Three of these (Alternaria, Fusarium, and Cladosporium) were recovered from senescent tissue of the water-inoculated plants that did not develop scorch. Species of Epicoccum and Phoma were each found on only one sample of the scorched tissue. These two genera were reported to be associated with leaf scorch when the disease was first described (20). These two fungi, along with others reported associated with the disease (20), are often saprophytes on dead plant tissue (2). No fungi could be consistently recovered from the diseased tissue that could not also be recovered from dead leaf tissue of the water-inoculated plants without scorch symptoms. X. fastidiosa can apparently cause the leaf scorch disease without the involvement of any specific fungi.

There is evidence that infection of hardwood trees with $X$. fastidiosa can predispose them to infection by other pathogens or damage from environmental stresses $(12,32)$. It may be that $X$. fastidiosa predisposes pecan leaf tissue to invasion by a number of weakly pathogenic or saprophytic fungi. This would explain the association of fungi with the 
pecan bacterial leaf scorch disease under natural conditions of orchards. However, these fungi were either not found or were not uniquely associated with greenhousemaintained plants inoculated with $X$. fastidiosa that had developed scorch disease. Fungi do not appear to be necessary for complete symptom development to occur.

$X$. fastidiosa has been found associated with scorch diseased leaves from several other cultivars (R. Sanderlin, unpublished). Additional work is needed to verify that this bacterium is the cause of leaf scorch in these cultivars. $X$. fastidiosa is the primary cause of the disease recognized as FLS in the Cape Fear cultivar; therefore, the name pecan bacterial leaf scorch is proposed as a new common name to replace FLS as the descriptive name of this disease.

Symptoms and patterns of disease expression of pecan bacterial leaf scorch are similar to the general description of other leaf scorch diseases of hardwoods caused by $X$. fastidiosa $(8,12,28)$ and Pierce's disease of grape (28). Leaf scorch diseases of hardwood trees caused by $X$. fastidiosa that have symptoms similar to pecan leaf scorch include mulberry leaf scorch (15), leaf scorch of red maple (34), plum leaf scald $(14,29)$, live oak scorch (24), red oak leaf scorch (3), and pear leaf scorch (17). Typically, in this group of diseases, necrosis develops at leaf margins during mid- to late summer, the necrosis migrates toward the midrib and base of the leaf and is often bordered by zones of dark reddish-brown tissue, and affected leaves abscise prematurely. The pattern of disease development on pecan is similar to sycamore (32), elm, and mulberry leaf scorch (33). Symptoms may be limited to individual limbs or appear throughout the tree. Terminal leaves of a branch are usually the last ones to develop scorch.

There is some symptom variation within the leaf scorch diseases of hardwoods induced by $X$. fastidiosa. For example, with almond leaf scorch, the affected leaves remain on the trees until fall defoliation $(5,25)$, whereas the diseased pecan leaflets typically drop soon after onset of symptoms. Dieback of scorch-affected limbs is common with elm, red oak, and sycamore (33). Limb dieback has not been observed to be common with pecan leaf scorch, which is more typical of red maple and mulberry (33). On pecan, affected limbs develop symptoms year after year, sometimes with little increase of symptoms through the rest of the tree. The trees produce healthy-looking foliage on affected limbs in the spring, but the foliage develops disease symptoms during summer followed by premature defoliation. This same annual pattern has been described in some other hardwood leaf scorch diseases $(9,33)$. In several diseases caused by $X$. fastidiosa, the host is eventually killed $(11,14,27,28)$. Death of pecans affected with leaf scorch has not been recorded.
For disease development and symptom expression in leaf scorch diseases, the bacteria must multiply and move systemically within the plant $(10,12)$. In the pathogenicity tests reported here, inoculations were made to the main stem of either the seedling or grafted tree. Symptom development occurred on the foliage, and the bacterium was recovered from the diseased leaves 2 to 4 months after inoculation. This indicates that $X$. fastidiosa is able to multiply and move systemically within pecan tissue.

Occasionally, ELISA indicated the presence of the bacterium in symptomless pecan leaf tissue. Other studies have indicated the occasional detection of the bacterium in symptomless tissue either through serology or culturing $(15,32,33)$. Symptomless trees of peach, in which the bacterium was detected, later developed the disease in almost all of the trees (35). The bacterium can sometimes increase to concentrations detectable by serology without the expression of visible symptoms.

All insect vectors of this bacterium feed either exclusively or primarily in xylem tissue and include leafhoppers, spittlebugs, and cicadas (26). The best documented among these insects on pecan are spittlebugs (Clastoptera achatina and C. obtusa), which are frequently found in spittle masses on the ends of terminals of pecan in the spring and early summer. Studies are planned to determine if these spittlebugs are vectors of $X$. fastidiosa. Some of the plants that have been identified as reservoirs of the bacterium, such as johnson grass and bermuda grass, are endemic in southeastern U.S. pecan orchards. Surveys will be made for suctorial insects that feed on the reservoirs and may subsequently transmit the bacterium to pecan. The species of xylem-feeding insects appear to be limited on pecan; therefore, control of such insects, along with the planting of tolerant or resistant cultivars, may provide a method to slow the spread of pecan bacterial leaf scorch in commercial orchards.

This study was confined to one cultivar because symptoms in other cultivars are not always as distinct and may be confused with foliar problems caused by nutritional imbalances (19). ELISA, along with careful observation of symptom development, will be used to separate pecan bacterial leaf scorch from nutritional problems, such as potassium deficiency, in an evaluation of cultivar susceptibility to the disease.

\section{LITERATURE CITED}

1. Alben, A. O. 1958. Waterlogging of subsoil associated with scorching and defoliation of Stuart pecan trees. Am. Soc. Hortic. Sci. 72:219-223.

2. Barnett, H. L., and Hunter, B. B. 1987. Illustrated Genera of Imperfect Fungi. 4th ed. Macmillan Publishing Co., New York.

3. Chang, C. J., and Walker, J. T. 1988. Bacterial leaf scorch of northern red oak: Isolation, cultivation, and pathogenicity of a xylemlimited bacterium. Plant Dis. 72:730-733.

4. Davis, M. J., French, W. J., and Schaad, N. W. 1981. Axenic culture of the bacteria associated with phony disease of peach and plum leaf scald. Curr. Microbiol. 6:309-314.

5. Davis, M. J., Thompson, S. V., and Purcell, A H. 1980. Etiological role of the xylem- limited bacterium causing Pierce's disease and almond leaf scorch. Phytopathology 70:472-475.

6. Gossard, A. C. 1961. Some causes and effects of pecan leaf scorch. Proc. Southeast. Pecan Grow. Assoc. 54:43-46.

7. Gottwald, T. R. 1994. Diseases of pecan (Carya illinoensis (Wang.) Koch). In: Common Names of Plant Diseases. APS, St. Paul, MN.

8. Hammerschlag, R. Sherald, J., and Kostka, S. 1986. Shade tree leaf scorch. J. Arboric. $12: 38-43$

9. Hearon, S. S., Sherald, J. L., and Kostka, S. J. 1980. Association of xylem-limited bacteria with elm, sycamore, and oak leaf scorch. Can. J. Bot. 58:1986-1993.

10. Hill, B. L., and Purcell, A. H. 1995. Multiplication and movement of Xylella fastidiosa within grapevine and four other plants. Phytopathology 85:1368-1372.

11. Hopkins, D. L. 1977. Diseases caused by leafhopper-borne, rickettsia-like bacteria. Annu. Rev. Phytopathol. 15:277-294.

12. Hopkins, D. L. 1989. Xylella fastidiosa: Xylem-limited bacterial pathogen of plants. Annu. Rev. Phytopathol. 27:271-290.

13. Hopkins, D. L., and Adlerz, W. C. 1988. Natural hosts of Xylella fastidiosa in Florida. Plant Dis. 72:429-431.

14. Kitajima, E. W., Bakarcic, M., and FernandezValiela, M. V. 1975. Association of rickettsialike bacteria with plum leaf scald disease. Phytopathology 65:476-479.

15. Kostka, S. J., Tattar, T. A., Sherald, J. L., and Hurtt, S. S. 1986. Mulberry leaf scorch, new disease caused by a fastidious, xylem-inhabiting bacterium. Plant Dis. 70:690-693.

16. Latham, A. J., Bowen, K. L., and Campbell, H, L. 1995. Occurrence of Glomerella cingulata in pecan nut shucks and its association with fungal leaf scorch. Plant Dis. 79:182185.

17. Leu, L. S., and Su, C. C. 1993. Isolation, cultivation, and pathogenicity of Xylella fastidiosa, the causal bacterium of pear leaf scorch disease in Taiwan. Plant Dis. 77:642646.

18. Littrell, R. H. 1974. Fungal leaf scorch of pecan. Proc. Southeast. Pecan Grow. Assoc. 67:143-146.

19. Littrell, R. H. 1989. Fungal leaf scorch in pecan production. Pages 134-135 in: Pecan Production in the Southeast: A Guide for Growers. W. D. Goff, J. R. McVay, and W. S. Gazaway, eds. Ala. Coop. Ext. Serv. Auburn Univ. Circ. ANR-459.

20. Littrell, R. H., and Worley, R. E. 1972. Mycoflora associated with leaf scorch of pecan. (Abstr.) Phytopathology 62:805.

21. Littrell, R. H., and Worley, R. E. 1973. Foliar fungicides, leaf inhabiting fungi, and development of leaf scorch. Proc. Southeast. Pecan Grow. Assoc. 66:73-78.

22. Littrell, R. H., and Worley, R. E. 1973. Fungicide effects on internal mycoflora of pecan leaflets and severity of leaf scorch. (Abstr.) Phytopathology 63:445.

23. Littrell, R. H., and Worley, R. E. 1975. Relative susceptibility of pecan cultivars to fungal leaf scorch and relationship to mineral composition of foliage. Phytopathology 65:717718 .

24. McGovern, R. J., and Hopkins, D. L. 1994. Association of Xylella fastidiosa with leaf scorch and decline of live oak in Florida. Plant Dis. 78:924. 
25. Mircetich, S. M., Lowe, S. K., Moller, W. J., and Nyland, G. 1976. Etiology of almond leaf scorch disease and transmission of the causal agent. Phytopathology 66:17-24.

26. Purcell, A. H., and Hopkins, D. L. 1996. Fastidious xylem-limited bacterial plant pathogens. Annu. Rev. Phytopathol. 34:131151.

27. Purcell, A. H., Saunders, S. R., Hendson, M. Grebus, M. E., and Henry, M. J. 1999. Causal role of Xylella fastidiosa in oleander leaf scorch disease. Phytopathology 89:53-58.

28. Raju, B. C., and Wells, J. M. 1986. Diseases caused by fastidious xylem-limited bacteria and strategies for management. Plant Dis. 70:182-186.

29. Raju, B. C., Wells, J. M., Nyland, G., Brlansky, R. H., and Lowe, S. K. 1982. Plum leaf scald: Isolation, culture, and pathogenicity of the causal agent. Phytopathology 72:1460-1466.

30. Reilly, C. C., and Reynolds, K. L. 1994. Fungi involved in fungal leaf scorch and the shuck disease complex of pecan. Proc. Southeast. Pecan Grow. Assoc. 87:129-142.

31. Sanderlin, R. S. 1998. Evidence that Xylella fastidiosa is associated with pecan fungal leaf scorch. Plant Dis. 82:264.

32. Sherald, J. L., Hearon, S. S., Kostka, S. J., and Morgan, D. L. 1983. Sycamore leaf scorch: Culture and pathogenicity of fastidious $\mathrm{xy}-$ lem-limited bacteria from scorch-affected trees. Plant Dis. 67:849-852.

33. Sherald, J. L., and Lei, J. D. 1991. Evaluation of a rapid ELISA test kit for detection of $X y$ lella fastidiosa in landscape trees. Plant Dis.
75:200-203.

34. Sherald, J. L., Wells, J. M., Hurtt, S. S., and Kostka, S. J. 1987. Association of fastidious, xylem-inhabiting bacteria with leaf scorch in red maple. Plant Dis. 71:930-933.

35. Wells, J. M., Weaver, D. J., and Raju, B. C. 1980. Distribution of rickettsia-like bacteria in peach, and their occurrence in plum, cherry, and some perennial weeds. Phytopathology 70:817-820.

36. Worley, R. 1983. Effects of potassium and nitrogen on leaf scorch and yield of 'Desirable' pecans. Proc. Southeast. Pecan Grow. Assoc. 76:127-131.

37. Worley, R. E., and Littrell, R. H. 1973. Effect of fungicides on nut quality and control of pecan scab and premature defoliation. J. Am. Soc. Hortic. Sci. 98:102-105. 